\title{
Drug-nutrient interactions: inhibition of amino acid intestinal absorption by fluoxetine
}

\author{
Elena Urdaneta ${ }^{1}$, Isabel Idoate ${ }^{2}$ and Jesús Larralde ${ }^{1} *$ \\ ${ }^{1}$ Departamento de Fisiología y Nutrición, Universidad de Navarra, C/Irunlarrea s/n, 31008 Pamplona, Spain \\ ${ }^{2}$ Departamento de Bioquímica, Hospital Virgen del Camino, C/Irunlarrea no. 4, 31008 Pamplona, Spain
}

(Received 23 September 1997-Revised 26 November 1997-Accepted 5 December 1997)

\begin{abstract}
Fluoxetine is one of the most widely used antidepressants and nowadays it is also being used to manage obesity problems. In our laboratory we demonstrated that the drug inhibited sugar absorption (Monteiro et al. 1993). The aim of the present work was to determine the effect of fluoxetine on intestinal leucine absorption. Using a procedure of successive absorptions in vivo the drug diminished amino acid absorption by $30 \%(P<0.001)$. Experiments in vitro in isolated jejunum also revealed a reduction in leucine uptake of $37 \%(P<0.001)$. In both cases fluoxetine only affected mediated transport without altering diffusion. In a preparation enriched in basolateral membrane, fluoxetine inhibited the $\mathrm{Na}^{+}, \mathrm{K}^{+}$-ATPase (EC 3.6.1.37) activity (55\%; $P<0.001)$ in a non-competitive manner with an inhibition constant $\left(K_{\mathrm{i}}\right)$ value of $0.92 \mathrm{mM}$. Leucine uptake by brush-border membrane vesicles was diminished by the drug (a reduction of $48 \%$ was observed at $30 \mathrm{~s}, P<0.001$ ); only the apical $\mathrm{Na}^{+}$-dependent transport system of the amino acid was modified and the inhibition was non-competitive. Leucine uptake in the presence of lysine indicated that transporter B was involved. These results suggest that fluoxetine reduces leucine absorption by its action on the basolateral and apical membrane of the enterocyte; the nutritional status of the patients under drug treatment may be affected as neutral amino acid absorption is decreased.
\end{abstract}

Fluoxetine: Drug-nutrient interactions: Intestinal absorption

Fluoxetine (FLX), a selective serotonin reuptake inhibitor, is one of the most widely used antidepressants (Bauman, 1996). Moreover, FLX has been reported to promote weight reduction (O'Kane et al. 1994), to treat obsessivecompulsive disorders (Fulton \& McTavish, 1995) and the premenstrual syndrome (Steiner et al. 1995). Its leptogenic action could be attributed to an effect on the central nervous system (Angel et al. 1988). Compared with other tri- and tetracyclic antidepressants, FLX has more gastrointestinal side-effects such as nausea, soft stools and diarrhoea. When administered for prolonged periods, adverse effects such as intestinal interactions with gastrointestinal components might occur. In fact, a previous study of this antidepressant found that FLX diminished intestinal sugar absorption (Monteiro et al. 1993) and therefore the study of its effect on another nutrient group, such as amino acids, could be of interest.

Amino acid transport is more complex than sugar absorption as many transporters are involved in this process. At least six different transport systems for neutral amino acids have been identified on the brush-border membrane of enterocytes (Ganapathy et al. 1994); two $\mathrm{Na}^{+}$-independent and the rest $\mathrm{Na}^{+}$-dependent systems.

We chose to use a neutral, essential amino acid, Lleucine. The aim of the present study was to investigate the effect of FLX on leucine absorption in the small intestine using in vivo and in vitro methods. This included the study of the uptake of L-leucine using isolated jejunum, the measurement of fluxes across the gut wall, basolateral $\mathrm{Na}^{+}, \mathrm{K}^{+}$-ATPase (EC 3.6.1.37) activity and uptake by brush-border membrane vesicles (BBMV).

\section{Materials and methods}

\section{Chemicals}

FLX (Lilly Indiana Madrid, Spain) was kindly donated. L- $\left[1-{ }^{14}\right.$ C]leucine (specific radioactivity $1850-2220$ $\mathrm{MBq} / \mathrm{mmol}$ ) was purchased from Amersham International plc (Amersham, Bucks., UK). L-Leucine, mannitol, ouabain, 
imidazole, Triton X-100, ATP, bovine serum albumin and Percoll were bought from Sigma Chemical Co. (St Louis, MO, USA). Ammonium molybdate and 1-amino-2naphthol-4-sulfonic acid were acquired from Fluka (Buchs, Switzerland). Scintillators Formula 989 (for liquid samples) and Optiphase 'Hisafe' 3 (for solid samples) were from Du Pont de Nemours (Brussels, Belgium) and LKB (Milton Keynes, Beds., UK) respectively. Cellulose nitrate filters (type HAWP $0.45 \mu \mathrm{m}, 25 \mathrm{~mm}$ diameter) were from Millipore (Madrid, Spain). All other chemicals were commercial products of reagent grade. The FLX concentration used was $0.3 \mathrm{~mm}$ (this concentration is in the range used in animals), except in kinetic studies. Radioactivity was determined on a liquid scintillation counter (Wallac 1409; Pharmacia, Barcelona, Spain).

\section{Animals}

Animals were handled according to the European Council Legislation 86/609/EEC on experimental animal protection. Male Wistar rats $(180-200 \mathrm{~g}$ body weight) were obtained from the Center of Applied Pharmacology (CIFA, Pamplona, Spain). The intestinal segment used was the jejunum and the animals were anaesthetized with subcutaneous doses of sodium pentothal $(60 \mathrm{mg} / \mathrm{kg})$.

\section{Amino acid absorption in vivo}

The procedure of successive absorptions in a closed circuit has already been described elsewhere (Ponz et al. 1979). Briefly, a jejunal loop of $150 \mathrm{~mm}$, starting $50 \mathrm{~mm}$ distal to the ligament of Treitz, was isolated between two glass cannulas, while the mesenteric vasculature of the loop was maintained. At each end of the loop an incision was made, and a cannula was introduced into it. The other sides of the cannulas were connected to tygon tubes and the tubes were also connected to a perfusion system, equipped with a constant-flow electric pump (Microperpex, model 2123, LKB Produkter, Milton Keynes, Beds., UK). The loop was reinserted in the abdominal cavity and the abdomen was closed. The anaesthetized animal and all the perfusion solutions were kept at $37^{\circ}$. The loop was first rinsed with $50 \mathrm{ml}$ saline solution $\left(140 \mathrm{mM}-\mathrm{NaCl}, 10 \mathrm{mM}-\mathrm{KHCO}_{3}\right.$, $0.4 \mathrm{mM}-\mathrm{KH}_{2} \mathrm{PO}_{4}, \quad 2.4 \mathrm{mM}-\mathrm{K}_{2} \mathrm{HPO}_{4}, \quad 1.2 \mathrm{mM}-\mathrm{CaCl}_{2}$ and $1.2 \mathrm{mM}^{-\mathrm{MgCl}_{2}} ; \mathrm{pH} \mathrm{7.4)}$ and then perfused with the same buffer containing $0.5 \mathrm{mM}-\mathrm{L}-$ leucine and $0.37 \mathrm{kBq} / \mathrm{ml}$ $\left[{ }^{14} \mathrm{C}\right]$ leucine for six successive $10 \mathrm{~min}$ intervals. The effect of the drug was measured by including it at a concentration of $0.3 \mathrm{mmol} / 1$ in the second of these perfusion periods. Perfusions with or without FLX were performed in twelve animals. The volume perfused was $10 \mathrm{ml}$. Between perfusion periods the intestine was washed with saline for 5 min. Leucine absorption was estimated as the difference between the amino acid in the solution before and after perfusion. Results are expressed as $\mu \mathrm{mol}$ leucine $/ \mathrm{cm}$ per $10 \mathrm{~min}$. To evaluate both transport components, mediated and non-mediated transport, $60 \mathrm{mM}$-L-alanine (Lerner \& Larimore, 1986) was added, with $0.5 \mathrm{mM}$-leucine in the perfusate. The $\mathrm{NaCl}$ concentration in the buffer was reduced to maintain the osmolality. Twelve animals were perfused, with or without FLX.

\section{Amino acid uptake in isolated jejunum}

About $200 \mathrm{~mm}$ of the jejunum was quickly excised and rinsed with an ice-cold saline solution. To perform uptake experiments, pieces of the intestine, each weighing about $50 \mathrm{mg}$, were incubated and continuously oxygenated $\left(\mathrm{O}_{2}-\right.$ $\left.\mathrm{CO}_{2}, 95: 5, \mathrm{v} / \mathrm{v}\right)$ in the saline solution described earlier. The incubations took place at $37^{\circ}$ and $0-4^{\circ}$, with $0.5 \mathrm{mM}-\mathrm{L}-$ leucine and $0.37 \mathrm{kBq} / \mathrm{ml}$ radioactive substrate with or without FLX, for 5, 15, 30 and $45 \mathrm{~min}$. At the end of the incubation the tissues were washed in an ice-cold saline solution, blotted carefully to remove excess moisture, weighed wet and extracted by shaking for $24 \mathrm{~h}$ in $100 \mathrm{mM}-$ $\mathrm{HNO}_{3}\left(0-4^{\circ}\right)$. Fifteen animals were used for each incubation temperature, $37^{\circ}$ and $0-4^{\circ}$. The number of intestinal pieces taken from each animal ranged from sixteen to twenty-four. Two or three pieces were incubated in $10 \mathrm{ml}$ saline solution for each experimental condition and the mean of those results was taken as one uptake measurement. Values are expressed as $\mu \mathrm{mol} \mathrm{L}-\mathrm{leucine} / \mathrm{ml}$ intracellular water. Extracellular space was measured by incubating the tissue for $20 \mathrm{~min}$ with saline solution containing $\left.0.74 \mathrm{kBq} / \mathrm{ml} \mathrm{[}{ }^{3} \mathrm{H}\right] \mathrm{PEG}-4000$ (Amersham International). Following extraction the tissues were dried at $110^{\circ}$ for $48 \mathrm{~h}$, then re-weighed. Tissue water was calculated as the difference between wet and dry weights. FLX had no effect either on extracellular space, or on intracellular water (results not shown).

\section{Measurement of L-leucine flux across the gut}

The intestine was opened along the mesenteric border and mounted as a flat sheet in an Ussing-type chamber (Naftalin \& Curran, 1976). The bathing solutions of the mucosal and serosal tissue surfaces contained $0.5 \mathrm{~mm}$-L-leucine and were maintained at $37^{\circ}$. The tissue was preincubated for $20 \mathrm{~min}$. Mucosal-to-serosal fluxes were measured by adding $1.48 \mathrm{kBq} / \mathrm{ml}$ of radioactive L-leucine to the mucosal side. Every $20 \mathrm{~min}$, samples of $0.2 \mathrm{ml}$ were taken from the serosal side and radioactivity determined. Results are the means of twelve animals.

\section{Measurement of basolateral $\mathrm{Na}^{+}, \mathrm{K}^{+}$-ATPase activity}

A fraction enriched in basolateral membrane was obtained using the method of Del Castillo \& Robinson (1982). A jejunal segment was removed and opened longitudinally. The mucosa was scraped off and homogenized in $250 \mathrm{mM}-$ sucrose and $2 \mathrm{mM}$-Tris-HEPES ( $\mathrm{pH} \mathrm{7.2).} \mathrm{The} \mathrm{suspension}$ was centrifuged at $1500 \mathrm{~g}$ for $10 \mathrm{~min}$, the precipitate was resuspended in $2 \mathrm{M}$-sucrose and centrifuged once more at $12500 \mathrm{~g}$ for $10 \mathrm{~min}$. The supernatant fraction, diluted in seven volumes of distilled water, was centrifuged at $35000 \mathrm{~g}$ for $15 \mathrm{~min}$ and the precipitate was mixed with a solution of Percoll (116.7 ml/l), 2 M-sucrose and 2 mM-Tris (pH 7.2) and centrifuged at $50800 \mathrm{~g}$ for $1 \mathrm{~h}$. The Percoll fraction was centrifuged at $50800 \mathrm{~g}$ for another $1 \mathrm{~h}$ and the 
final pellet was resuspended in the required volume of $2 \mathrm{M}$ sucrose and 2 mM-Tris-HEPES ( $\mathrm{pH} \mathrm{7.2)} \mathrm{to} \mathrm{obtain} \mathrm{a} \mathrm{protein}$ concentration of $4-6 \mathrm{mg} / \mathrm{ml}$. The preparation obtained had a $\mathrm{Na}^{+}, \mathrm{K}^{+}$-ATPase activity 15 (SEM 0.5) times greater than that of the original tissue. Nevertheless, slight contamination with brush-border membrane was observed. The activity of sucrose $\alpha$-glucosidase (EC 3.2.1.48), a marker enzyme for the brush-border membrane (Van Beers et al. 1995), was reduced 16-fold compared with that of the original tissue. The ATPase activity was determined by the method of Jorgensen (1975) modified by Hardcastle et al. (1986). Ouabain ( $3 \mathrm{mmol} / \mathrm{l}$ ) was used to inhibit $\mathrm{Na}^{+}, \mathrm{K}^{+}$ATPase and its activity was calculated as the difference in ATPase activity in the absence and presence of ouabain. Twelve basolateral membrane preparations were used, each taken from five animals.

For the determination of the $\mathrm{Na}^{+}, \mathrm{K}^{+}$-ATPase kinetic parameters in the presence of FLX, $\mathrm{Na}^{+}, \mathrm{K}^{+}$-ATPase was assayed with different ATP concentrations (0.1$10.0 \mathrm{mmol} / \mathrm{l}$ ). The concentration of the drug in the incubation medium ranged between 0.0 and $1.0 \mathrm{mmol} / \mathrm{l}$. Data were analysed by the Lineweaver-Burk plot.

\section{Preparation of brush-border membrane vesicles}

The brush-border membrane was prepared by the method of Shirazi-Beechey et al. (1990). Briefly, this involved suspending the everted intestine in a buffer containing $2 \mathrm{mM}$-HEPES/Tris $(\mathrm{pH} 7.1)$ and $100 \mathrm{mM}$-mannitol, and stirring in a Vibro-Mixer (model E-1; Sorvall, Newtown, $\mathrm{CT}$, USA) for $3 \mathrm{~min}$. $\mathrm{A} \mathrm{MgCl}_{2}$ solution was added to achieve a final concentration of $10 \mathrm{mmol} / \mathrm{l}$ and the preparation was stirred for $30 \mathrm{~min}$ at $0-4^{\circ}$. After centrifuging several times, the final pellet of the vesicle preparation was suspended in the desired volume of $300 \mathrm{mM}$-mannitol, $0.1 \mathrm{mM}-\mathrm{MgSO}_{4}$ and $10 \mathrm{mM}$-Tris-HEPES buffer ( $\mathrm{pH} \mathrm{7.4)}$ (load solution), using a no. 27 gauge needle. The final protein concentration range was $7-10 \mathrm{mg} / \mathrm{ml}$. The enrichment of the specific activity of sucrose $\alpha$-glucosidase was 10.5 (SEM 1.0)-fold. The contamination with the basolateral membrane was very low $\left(\mathrm{Na}^{+}, \mathrm{K}^{+}\right.$-ATPase activity was reduced 20 -fold with respect to homogenate). Protein was determined according to the method of Bradford (1976), with bovine albumin as standard. For BBMV experiments fifteen preparations were made, each one from five animals.

\section{Transport studies}

Time-course studies of amino acid uptake were performed using a rapid filtration technique (Hopfer et al. 1975). A portion of the BBMV preparation $(5 \mu \mathrm{l})$ was added to the incubation medium $(45 \mu \mathrm{l})$ to start the experiments. The total L-leucine uptake was divided into three components, namely $\mathrm{Na}^{+}$-dependent, $\mathrm{Na}^{+}$-independent and diffusion. In order to separate these systems, three parallel time-course experiments were necessary: (1) under a $\mathrm{Na}^{+}$gradient $(0 \mathrm{mM}$ in : $100 \mathrm{mM}$ out $)$ and at $25^{\circ}$, to measure the total uptake; (2) in the absence of $\mathrm{Na}^{+}$and with a $\mathrm{K}^{+}$gradient $\left(0 \mathrm{mM}\right.$ in : $100 \mathrm{mM}$ out) and at $25^{\circ}$, to measure $\mathrm{Na}^{+}$- independent uptake plus diffusion; (3) in the presence of a $\mathrm{Na}^{+}$gradient $(0 \mathrm{mM}$ in : $100 \mathrm{mM}$ out $)$ and at $0-4^{\circ}$, to evaluate the diffusion component.

$\mathrm{Na}^{+}$-dependent uptake, with or without FLX, was calculated as the difference in uptake between the first two conditions. The difference between the second and third conditions was assumed to be equivalent to $\mathrm{Na}^{+}$independent uptake. The final concentration of the incubation medium was: $10 \mathrm{~mm}$-Tris-HEPES buffer ( $\mathrm{pH} 7.4$ ), $0.1 \mathrm{mM}^{-\mathrm{MgSO}_{4}}, \quad 100 \mathrm{~mm}$-mannitol, $100 \mathrm{mM}-\mathrm{NaSCN}$ or $100 \mathrm{mM}-\mathrm{KSCN}, 0.5 \mathrm{mM}$-L-leucine and $50 \mu \mathrm{M}$-radiolabelled substrate. At the stated times the incubation was stopped by the addition of $3 \mathrm{ml}$ ice-cold solution containing $150 \mathrm{~mm}$ KSCN and $10 \mathrm{mM}$-Tris-HEPES buffer ( $\mathrm{pH} \mathrm{7.4).} \mathrm{The}$ suspension was poured onto a prewetted Millipore filter that was washed twice with $3 \mathrm{ml}$ ice-cold stop solution, dissolved in scintillator 'Hisafe 3' and counted. Nonspecific binding to the filter was subtracted from the uptake value.

\section{Kinetics}

The initial leucine uptake rate as a function of external leucine concentration can be used to calculate the kinetic parameters. A time of $3 \mathrm{~s}$ was chosen to measure initial uptake. Some leucine experiments were determined in the presence of an inward $\mathrm{Na}^{+}$gradient and others in a $\mathrm{K}^{+}$ gradient. These conditions should enable separation of $\mathrm{Na}^{+}$-dependent-carrier-mediated transport from $\mathrm{Na}^{+}$-independent plus the diffusion pathway.

Data were represented by an Eadie-Hofstee plot. In this plot, used when studying kinetics of transporters, the initial uptake rate (V) $v$. the initial uptake rate/substrate concentration (V/S) is represented (Harig et al. 1989). Analysis of the data to estimate the kinetic parameters was performed by a non-linear fitting of the initial uptake rate to the Michaelis-Menten equation using the program Sigma Plot (version 3.02; Jandel Scientific, Jandel Corporation, Palo Alto, CA, USA).

\section{Competitive studies}

L-Leucine uptake by BBMV was measured in the presence and absence of $10 \mathrm{~mm}$-lysine. The experiments were performed at $25^{\circ}$ and in a $\mathrm{Na}^{+}$gradient $(0 \mathrm{mM}$ in : $100 \mathrm{mM}$ out) condition. The uptake was measured at $30 \mathrm{~s}$. L-Leucine uptake measured in the presence of an excess of lysine is mainly through system B (Munck, 1995).

\section{Statistics}

Results are expressed as means with their standard errors. Data were analysed statistically using Student's $\mathbf{t}$ test. Differences were considered significant if the $P$ value was $<0.05$.

\section{Results \\ Effect in vivo of fluoxetine}

The effect in vivo was measured over six successive $10 \mathrm{~min}$ perfusion periods in the same animal, perfusing a saline 


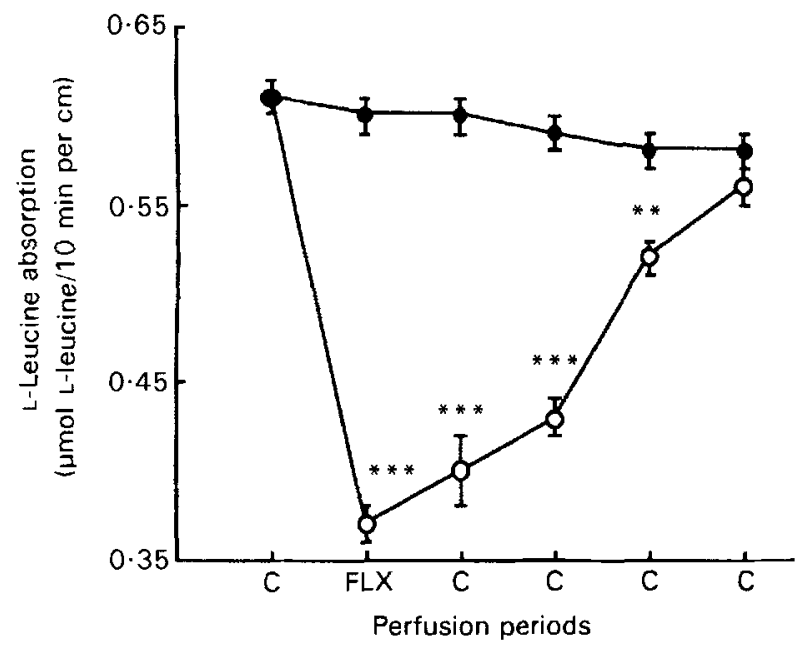

Fig. 1. Effect of the antidepressant fluoxetine (FLX) on absorption of L-leucine by the intestine in vivo. Six perfusion periods of $10 \mathrm{~min}$ were carried out in the same animal. During the control period $(C ; O)$ $0.5 \mathrm{~mm}-\mathrm{L}$-leucine was perfused. During the FLX periods $(O)$ perfusion was with either $0.5 \mathrm{~mm}$-L-leucine (periods $1,3,4,5$ and 6 ) or $0.5 \mathrm{~mm}$ L-leucine $+0.3 \mathrm{~mm}-\mathrm{FLX}$ (period 2). For details of procedures, see pp. 440-441. Values are means for twelve animals, with their standard errors represented by vertical bars. Mean values were significantly different from control, ${ }^{\star \star} P<0.01,{ }^{\star \star \star} P<0.001$.

solution with $0.5 \mathrm{mM}$-L-leucine during each period except in the second, where the amino acid and the drug were perfused simultaneously. FLX reduced amino acid absorption (Fig. 1) during the second period of perfusion $(P<0.001)$. This inhibition was diminished in subsequent periods when only leucine was perfused and returned to the control value in period six. To find out which of the two pathways, diffusion or mediated-transport, was affected by FLX, the effect of the drug was measured in the presence of a high concentration $(60 \mathrm{mM})$ of another amino acid (Lalanine) that shares the same transporters with L-leucine. In

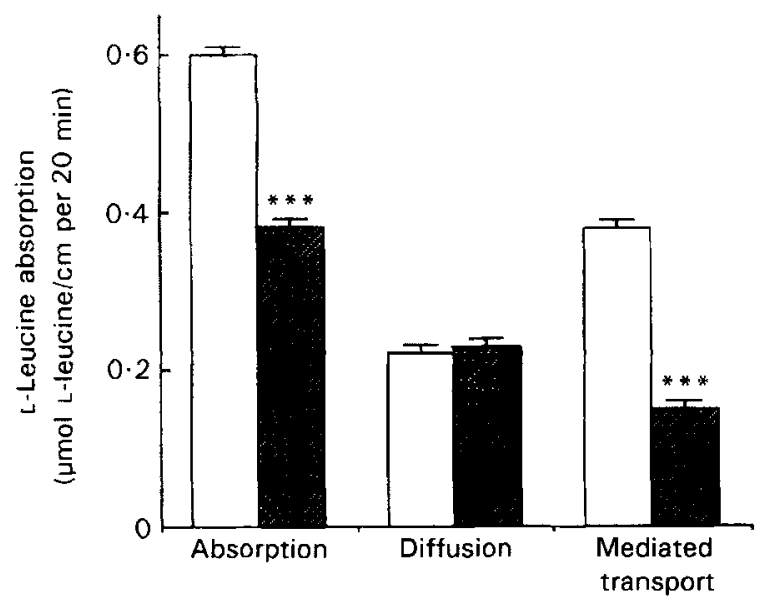

Fig. 2. Effect of fluoxetine ( $F L X)$ on the mediated and non-mediated transport of L-leucine in vivo. Animals were perfused with $0.5 \mathrm{mM}-\mathrm{L}$ -

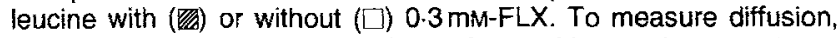
$60 \mathrm{mM}-\mathrm{L}$-alanine was added to the perfusate. Mediated transport was taken as the difference between absorption and diffusion. For details of procedures, see pp. 440-441. Values are means for twelve animals, with their standard errors represented by vertical bars. Mean values were significantly different from control, ${ }^{\star \star \star} P<0.001$. the presence of alanine, leucine carrier-mediated transport was practically abolished, and any absorption was mediated by diffusion. The mediated transport was calculated as the difference between absorption without L-alanine and absorption with L-alanine. The antidepressant only affected the carrier-mediated transport system (Fig. 2).

\section{Amino acid uptake and mucosal to serosal flux}

FLX inhibited leucine uptake significantly by $37-42 \%$ (Table 1). The effect was observed at all incubation times $(5-45 \mathrm{~min})$ and was not affected by the time of the incubation. On the other hand, leucine uptake was not altered by the drug at $0-4^{\circ}$, when only diffusion was measured. These findings, in agreement with those obtained in vivo, indicated that only mediated transport was reduced by FLX. Mucosal-to-serosal fluxes were also inhibited by FLX; under control conditions, L-leucine mucosal-toserosal flux was 0.31 (SEM 0.03$) \mu \mathrm{mol} / \mathrm{cm}^{2}$ per $\mathrm{h}$, with FLX this flux diminished to a value of 0.19 (SEM $0.02) \mu \mathrm{mol} / \mathrm{cm}^{2}$ per h $(P<0.001)$.

\section{Effect of fluoxetine on $\mathrm{Na}^{+}, K^{+}$-ATPase activity}

The effect of FLX on the $\mathrm{Na}^{+}, \mathrm{K}^{+}$-ATPase activity was measured in a preparation of purified basolateral membrane with little brush-border membrane contamination. $\mathrm{Na}^{+}, \mathrm{K}^{+}$ATPase activity was measured indirectly using ouabain as an inhibitor. FLX reduced the activity of this enzyme by $55 \%$ (Fig. 3) but did not affect that of the ouabaininsensitive ATPase (non- $\mathrm{Na}^{+}, \mathrm{K}^{+}$-dependent ATPase). Kinetic studies were performed to clarify the inhibitory effect of the antidepressant. As shown in Fig. 4, the Lineweaver-Burk plot analysis demonstrated that FLX inhibited the enzyme activity in a non-competitive manner, indicating that FLX does not compete with ATP for its active site. For control, an apparent maximum velocity ( $V_{\text {max }}$ ) of $654.0 \mu \mathrm{mol} \mathrm{P}_{\mathrm{i}} / \mathrm{mg}$ protein per $\mathrm{h}$ and an apparent Michaelis constant $\left(K_{\mathrm{m}}\right)$ of $2.1 \mathrm{mmol} / 1$ were recorded. The apparent inhibitor constant $\left(K_{\mathrm{i}}\right)$ value, determined by the replot of slopes of the Lineweaver-Burk Plot, was $0.92 \mathrm{mmol} / 1$.

\section{Time courses of L-leucine uptake by brush-border membrane vesicles}

As shown in Fig. 5, there was an overshoot of L-leucine uptake in the presence of a $\mathrm{Na}^{+}$-gradient $(100 \mathrm{mM}$ in: $0 \mathrm{mM}$ out) with a peak at about $30 \mathrm{~s}$. At this time the $\mathrm{Na}^{+}-$ dependent pathway contributed $91 \%$ of the total uptake. The uptake recorded in a $\mathrm{K}^{+}$-gradient was higher than the level of the passive diffusion of L-leucine. This indicated the presence of a $\mathrm{Na}^{+}$-independent pathway for L-leucine. This transport system measured at $30 \mathrm{~s}$ represented $5 \%$ of the total uptake. Diffusion, measured at the same experimental time, accounted for the remaining $4 \%$. FLX only affected the $\mathrm{Na}^{+}$-dependent transport system, without altering the other components.

In kinetic experiments the initial uptake rate of leucine through the $\mathrm{Na}^{+}$-dependent transport system was measured 
Table 1. Uptake of L-leucine by isolated jejunal rings in the presence or absence of fluoxetine (FLX) at $37^{\circ}$ and $0-4^{\circ} \dagger$ (Mean values with their standard errors for samples from fifteen animals)

L-Leucine uptake

( $\mu \mathrm{mol}$ L-leucine/ml intracellular water)

\begin{tabular}{|c|c|c|c|c|c|c|c|c|}
\hline \multirow[b]{3}{*}{ Time (min) } & \multicolumn{4}{|c|}{$37^{\circ}$} & \multicolumn{4}{|c|}{$0-4^{\circ}$} \\
\hline & \multicolumn{2}{|c|}{ Control } & \multicolumn{2}{|c|}{ FLX } & \multicolumn{2}{|c|}{ Control } & \multicolumn{2}{|c|}{ FLX } \\
\hline & Mean & SEM & Mean & SEM & Mean & SEM & Mean & SEM \\
\hline 5 & 1.23 & 0.04 & $0.77^{\star \star \star \star}$ & 0.03 & 0.29 & 0.01 & 0.27 & 0.01 \\
\hline 15 & 1.79 & 0.07 & $1.10^{\star \star \star}$ & 0.04 & 0.36 & 0.02 & 0.39 & 0.01 \\
\hline 30 & $2 \cdot 30$ & 0.08 & $1.35^{\star \star \star}$ & 0.07 & 0.50 & 0.03 & 0.51 & 0.01 \\
\hline 45 & $3 \cdot 12$ & 0.10 & $1.59^{\star \star \star *}$ & 0.09 & 0.56 & 0.03 & 0.56 & 0.02 \\
\hline
\end{tabular}

Mean values were significantly different from those for the control, ${ }^{* *} \boldsymbol{P}<0.001$.

+ For details of procedures, see pp. 440-441.

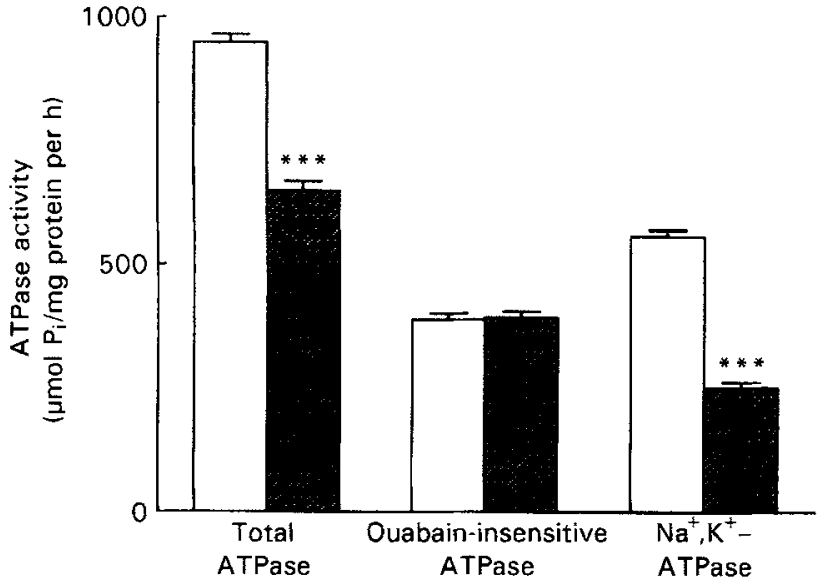

Fig. 3. Effect of the antidepressant fluoxetine (FLX) on the activity of basolateral ATPase. A preparation enriched in basolateral membrane was incubated at $37^{\circ}$ for $30 \mathrm{~min}$ with (圈) or without $(\square)$ $0.3 \mathrm{~mm}-\mathrm{FLX}$. Ouabain $(3 \mathrm{mmol} / \mathrm{l})$ was used to inhibit $\mathrm{Na}^{+}, \mathrm{K}^{+}$-ATPase and its activity was calculated as the difference between total ATPase and ATPase measured in the presence of ouabain, expressed as $\mu \mathrm{mol} P_{i} / \mathrm{mg}$ protein per $h$. For details of procedures, see pp. 440-441. Values are means for twelve preparations, with their standard errors represented by vertical bars. Mean values were significantly different from control, ${ }^{* * *} P<0.001$.

at seven different leucine concentrations, ranging from $0 \cdot 1$ to $5.0 \mathrm{mmol} / 1$ and four FLX concentrations, $0.3,0.5,0.7$ and $1.0 \mathrm{mmol} / \mathrm{l}$. The slope of the lines obtained in the presence of FLX did not differ from that of the control $(P<0.05)$, indicating a non-competitive inhibition (Fig. 6). FLX and leucine bind to different places of the $\mathrm{Na}^{+}$. dependent transport system.

By non-linear fitting of the data ( $r$ 0.998), an affinity constant of 2.22 (SEM 0.1 ) $\mathrm{mmol} / 1$ was obtained. In control conditions a $V_{\max }$ of 356.00 (SEM 9.0) pmol L-leucine $/ \mathrm{mg}$ protein per $3 \mathrm{~s}$ was recorded.

\section{Competitive studies}

In addition to the $\mathrm{B}$ transporter, $\mathrm{B}^{0,+}$ and $\mathrm{b}^{0,+}$ systems are present in the brush-border membranes of enterocytes (Pickel et al. 1993; Mailliard et al. 1995). One method of inhibiting the $\mathrm{B}^{0,+}$ system is to measure leucine uptake in the presence of an excess of lysine (Campa \& Kilberg, 1989; Munck, 1989; Magagnin et al. 1992).

In the presence of $10 \mathrm{mM}-\mathrm{L}-\mathrm{lys}$ sine, FLX reduced Lleucine uptake (control: 314 (SEM 12) v. FLX: 162 (SEM 6) $\mathrm{pmol} \mathrm{L-leucine} / \mathrm{mg}$ protein per $30 \mathrm{~s}$ to the same extent as when the basic amino acid was not present in the incubation medium (control: 471 (SEM 19) v. FLX: 212 (SEM 7) pmol L-leucine $/ \mathrm{mg}$ protein per $30 \mathrm{~s}$ ). This means that FLX affected the brush-border $\mathrm{Na}^{+}$-dependent neutral amino acid transport system (B) and had no effect on $\mathrm{B}^{0,+}$.

\section{Discussion}

FLX is one of the most widely used drugs today. The drug is a highly specific inhibitor of active serotonin reuptake into presynaptic nerve endings in the brain (Wong et al. 1975). In addition to its use as an antidepressant, it is also prescribed in obesity. Studies in animals have reported that FLX reduces food intake (Wong \& Yen, 1985) mainly suppressing the intake of high-carbohydrate diets (Luo \& $\mathrm{Li}, 1990$ ). Clinical studies have also shown it to promote weight reduction in obese subjects (Wise, 1992) and in obese patients with type 2 diabetes (Connolly et al. 1995); it even minimizes weight gain after smoking cessation (Spring et al. 1995). FLX action in obesity has been attributed to its anorexic effect mediated by serotonin (Blundell \& Hill, 1989). However, since FLX is an oral drug, a direct action on the intestine, such as interference with nutrient absorption, may also be possible. We therefore studied the effects of this antidepressant on the intestinal absorption of a neutral amino acid, L-leucine. This nutrient is transported at the apical membrane by a combination of the $\mathrm{B}, \mathrm{B}^{0,+}, \mathrm{b}^{0,+}$ and ASC systems (Ganapathy et al. 1994; Brandsch et al. 1995; Matthews et al. 1996) and also by the recently described $y^{+} L$ system (Jun et al. 1995). Studies carried out in vivo using the successive intestinal absorption technique, in which drug perfusion of the tissue was only carried out in the second perfusion period, showed that there was a strong inhibition of leucine absorption ( $30 \%$ ), but this was restored to the control value with time. Because leucine absorption by diffusion was not affected by this drug (Fig. 2), the inhibition observed was due to an effect on mediated transport systems. This phenomenon was also observed in 

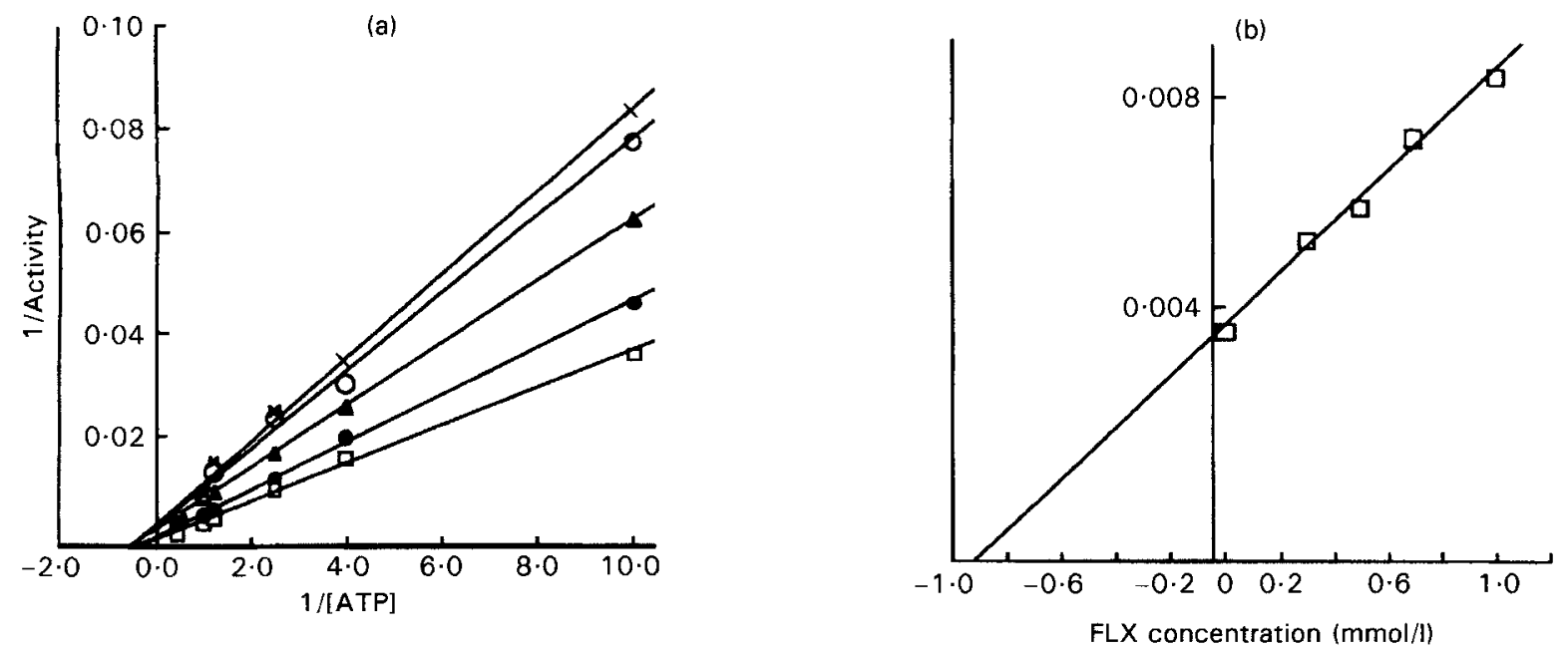

Fig. 4. Analysis of the inhibitory effect of fluoxetine ( $F L X)$ on the activity of $\mathrm{Na}^{+}, \mathrm{K}^{+}$-ATPase. (a) Analysis by the Lineweaver-Burk plot. Final concentrations of $\mathrm{FLX}$ were: 0 (control; $\square$ ), $0.3(0), 0.5(\Delta), 0.7(O)$ and $1.0(x) \mathrm{mmol} / \mathrm{l}$. Each value represents the mean of twelve results. (b) The re-plot of the slopes of the Lineweaver-Burk plot.

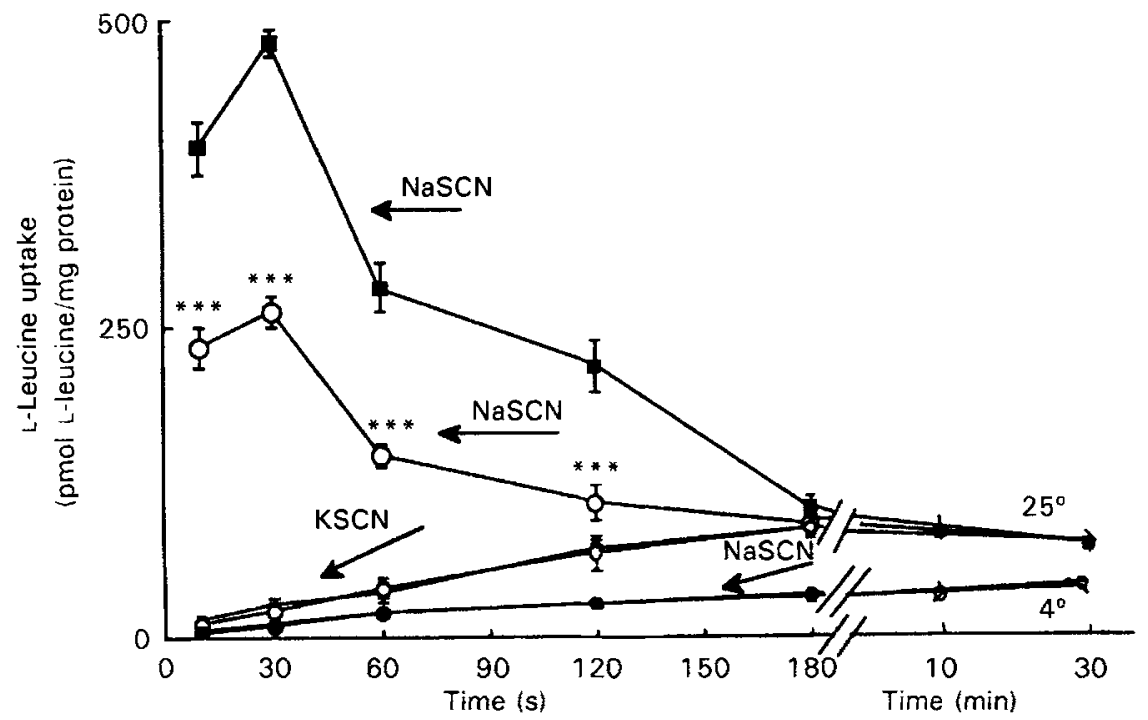

Fig. 5. Time course of L-leucine uptake by brush-border membrane vesicles in the presence (O) or absence ( $\square$ ) of $0.3 \mathrm{~mm}$-fluoxetine. Vesicles were loaded with $300 \mathrm{~mm}$-mannitol, $0.1 \mathrm{~mm}-\mathrm{MgSO}_{4}$ and $10 \mathrm{mM}$-HEPES-Tris buffer (pH 7.4). The incubation medium contained: $100 \mathrm{mM}-\mathrm{NaSCN}$ or KSCN, $100 \mathrm{~mm}$-mannitol, $0.1 \mathrm{mM}-\mathrm{MgSO}_{4}, 10 \mathrm{~mm}$-HEPES-Tris buffer $(\mathrm{pH} 7.4)$ and $0.5 \mathrm{~mm}$-L-leucine. Uptake studies were performed at $25^{\circ}$ and $4^{\circ}$. For details of procedures, see pp. 440-441. Values are means with their standard errors indicated by vertical bars for fifteen results made in triplicate. Control and fluoxetine results for KSCN and at $4^{\circ}$ are superimposed. Mean values were significantly different from control, ${ }^{\star * *} P<0.001$.

the study of the effect of cefroxadine and cephaloglycine on the absorption of amino acids (Barcina et al. 1988; Mendizabal et al. 1990, 1991).

In order to confirm the inhibition, we carried out experiments in vitro to determine the effects of the drug on the transport of leucine using two preparations, intestinal rings and transepithelial flow. The results using intestinal rings showed a strong and rapid inhibition of amino acid uptake by FLX $(37 \%, P<0.001)$. This was observed within $5 \mathrm{~min}$ and did not increase with time (Table 1). This inhibition appears to indicate the effect of FLX on mediated transport because it disappeared when the uptake was measured at $0-4^{\circ}$, a temperature at which mediated transport systems are inoperative. (McCloud et al. 1996). Results of transepithelial flow of the amino acid showed that mucosal-to-serosal flux was decreased. FLX may act directly on leucine uptake, or have an indirect effect. This latter possibility could be through FLX inhibition of serotonin reuptake, since serotonin significantly diminishes the uptake and the steady-state tissue accumulation of leucine (Salvador et al. 1996) and may also function as a neurotransmitter and a local paracrine modulator in the gastrointestinal tract (Gershon et al. 1985).

The data reveal that mediated transport of leucine is inhibited by FLX and therefore research on its effect on the $\mathrm{Na}^{+}, \mathrm{K}^{+}$-ATPase seemed logical. This enzyme, anchored on the basolateral membrane, plays a definitive role in the control of transmembrane $\mathrm{Na}$ and $\mathrm{K}$ gradients in the cell and thus is of importance in the $\mathrm{Na}^{+}$-dependent transport 


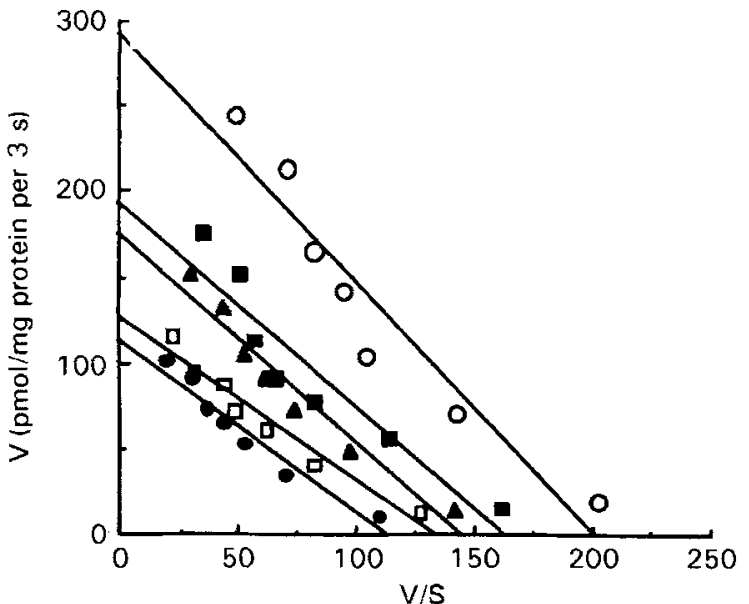

Fig. 6. Kinetic analysis of the inhibitory effect of fluoxetine (FLX) on $\mathrm{Na}^{+}$-dependent L-leucine uptake. The figure shows an EadieHoffstee plot of the $\mathrm{Na}^{+}$-dependent uptake measured at $3 \mathrm{~s}$ and $25^{\circ}(0)$. Control; (a), $0.3 \mathrm{~mm}-\mathrm{FLX} ;(\boldsymbol{\Delta}), 0.5 \mathrm{mM}$-FLX; $(\square), 0.7 \mathrm{~mm}$ FLX; (O), $1.0 \mathrm{~mm}-\mathrm{FLX}$; substrate concentration ranged from 0.1 to $5.0 \mathrm{~mm}$. The plot is of initial uptake rate (V) $\mathrm{V}$. initial uptake rate/substrate concentration $(V / S)$. Values are means for fifteen results.

system of leucine. Fig. 3 shows that FLX decreased the activity of this enzyme without affecting any other ATPase. This is a non-competitive enzyme inhibition and affects only the $\mathrm{Na}^{+}$-dependent amino acid transport system (Dixon \& Hokin, 1980). The $K_{\mathrm{i}}$ value obtained for FLX is low compared with that of some antibiotics that also inhibit $\mathrm{Na}^{+}, \mathrm{K}^{+}$-ATPase activity. This would be related to the extent to which the absorption is inhibited. For cefaclor we found a $K_{\mathrm{i}}$ of $4.0 \mathrm{mmol} / \mathrm{l}$, and a $1.0 \mathrm{mM}$ antibiotic concentration produced a $15 \%$ inhibition of the absorption (Idoate et al. 1996). A concentration of $0.3 \mathrm{mM}-\mathrm{FLX}$ reduced leucine absorption by $30 \%$ (Fig. 1).

To find out if FLX acted on the transport system of the apical membrane, BBMV were prepared. In this preparation FLX only affected the $\mathrm{Na}^{+}$-dependent transport system (Fig. 5), as determined by subtracting the uptake in the presence of a $\mathrm{K}^{+}$gradient from that in the presence of a $\mathrm{Na}^{+}$gradient, both measured at $25^{\circ}$. Kinetic studies confirmed that this inhibition was non-competitive (Fig. 6 , since the affinity constant of the amino acid for the transporter was not affected by the drug. Conversely, the maximum velocity of transport was reduced as the concentration of FLX was increased. These results indicated that FLX had a direct effect on apical $\mathrm{Na}^{+}$dependent L-leucine transport. When the uptake of $0.5 \mathrm{mM}$ L-leucine in the presence of $10 \mathrm{mM}$-lysine was measured, the inhibition caused by the drug was similar in the presence and absence of lysine. This indicates that $\mathrm{B}^{0,+}$ transporter is not affected and system B is involved.

Our results show that FLX has an action on the intestinal absorption of nutrients. We can conclude that FLX affects leucine transport by interacting with basolateral $\mathrm{Na}^{+}, \mathrm{K}^{+}$ATPase and the apical $\mathrm{Na}^{+}$-dependent transport system (system B). The $\mathrm{Na}^{+}, \mathrm{K}^{+}$-ATPase inhibition implies that transport of nutrients coupled with $\mathrm{Na}$ is reduced. Glucose is transported coupled with $\mathrm{Na}$ and a decrease in its absorption would be beneficial in obesity. On the other hand, a reduction in amino acid absorption may affect the nutritional status of patients under FLX therapy.

\section{Acknowledgements}

This work was supported by Ministerio de Sanidad y Consumo grant FIS 95/1663.

\section{References}

Angel I, Faranger MA, Sacatten B \& Langer SZ (1988) Mechanism of anoretic activity of serotonin reuptake inhibitors. British Journal of Pharmacology 93, 11-19.

Barcina Y, Ilundain A \& Larralde J (1988) Effect of amoxicillin, cephalexin and tetracycline- $\mathrm{HCl}$ on intestinal L-leucine transport in rat in vivo. Drug-Nutrient Interactions 5, 283-288.

Baumann S (1996) Pharmacokinetic-pharmacodynamic relationship of the selective serotonin reuptake inhibitors. Clinical Pharmacokinetics 31, 444-469.

Blundell JE \& Hill AJ (1989) Do serotoninergic drugs decrease energy intake by reducing fat or carbohydrate intake? Effect of d-fenfluramine with supplemented weight-increasing diets. Pharmacology, Biochemistry and Behavior 31, 773-778.

Bradford BB (1976) A rapid and sensitive method for the quantitation of microgram quantities of protein utilizing the principle of protein-dye binding. Analytical Biochemistry $\mathbf{7 2}$, 248-254.

Brandsch M, Brandsch R, Prasad MV, Ganapathy V, Hopfer U \& Leibach FH (1995) Identification of a renal cell line that constitutively expresses the kidney-specific high-affinity $\mathrm{H}^{+}$. peptide cotransporter. FASEB Joumal 9, 1489-1496.

Campa MJ \& Kilberg MS (1989) Characterization of neutral and cationic amino acid transport in Xenopus oocytes. Joumal of Cellular Physiology 141, 645-652.

Connolly VM, Gallagher A \& Kesson CM (1995) A study of fluoxetine in obese elderly patients with type 2 diabetes. Diabetic Medicine 12, 416-418.

Del Castillo JR \& Robinson JW (1982) Simultaneous preparation of basolateral and brush border membrane vesicles from guinea pig intestinal epithelium and the determination of the orientation of the basolateral membrane vesicles. Biochimica et Biophysica Acta 688, 45-56.

Dixon J \& Hokin L (1980) The reconstituted $\left(\mathrm{Na}^{+}, \mathrm{K}^{+}\right)$, ATPase is electrogenic. Journal of Biological Chemistry 255, 1068110686.

Fulton B \& McTavish D (1995) Fluoxetine: an overview of its pharmacodynamic and pharmacokinetic properties and review of its therapeutic efficacy in obsessive-compulsive disorder. CNS Drugs 3, 305-322.

Ganapathy V, Brandsch M \& Leibach FH (1994) Intestinal transport of amino acids and peptides. In Physiology of the Gastrointestinal Tract, p. 1773 [LR Johnson, editor]. New York: Raven Press.

Gershon MD, Takaki M, Tamir H \& Branchek T (1985) The enteric neural receptor for 5-hydroxytryptamine. Experientia 41, 863-868.

Hardcastle J, Hardcastle PT, Kelleher K, Henderson LS \& Fondacaro JB (1986) Effect of auranofin on absorptive processes in the rat small bowel. Joumal of Rheumatology 13, 541-546.

Harig JM, Barry JA, Rajendran VM, Soergel KH \& Ramaswany K (1989) D-Glucose and L-leucine transport by human brushborder membrane vesicles. American Joumal of Physiology 256, G618-G623. 
Hopfer U, Sigrist-Nelson K, Perrotto J \& Murer H (1975) Intestinal sugar transport: studies with isolated plasma membranes. Annals of the New York Academy of Sciences 264, 414427.

Idoate I, Mendizábal MV, Urdaneta E \& Larralde J (1996) Interactions of cephradine and cefaclor with the intestinal absorption of D-galactose. Journal of Pharmacy and Pharmacology 48, 645-650.

Jorgensen JL (1975) Techniques for the study of steroids effects on membraneous $\left(\mathrm{Na}^{+}-\mathrm{K}^{+}\right)$ATPase. Methods in Enzymology 36, 434-439.

Jun FY, Prasad PD, Leibach FH \& Ganapathy V (1995) The amino acid transport system $\mathrm{y}+\mathrm{L}$ induced in Xenopus laevis oocytes by human choriocarcinoma cell (JAR) mRNA is functionally related to the heavy chain of the $4 \mathrm{~F} 2$ cell surface antigen. Biochemistry 34, 8744-8751.

Luo S \& Li TS (1990) Food intake and selection pattern of rats treated with dexfenfluramine, fluoxetine and RU 24969. Brain Research Bulletin 24, 729-733.

Lemer J \& Larimore DL (1986) Comparative aspects of the apparent Michaelis constant for neutral amino acid transport in several animal tissues. Comparative Biochemistry and Physiology 84B, 235-241.

McCloud E, Ma TY, Grant KE, Mathis RK \& Said HM (1996) Uptake of L-carnitine by a human intestinal epithelial cell line, Caco-2. Gastroenterology 111, 1534-1540.

Magagnin S, Bertarn J \& Werner A (1992) Poly (A) ${ }^{+}$RNA from rabbit intestinal mucosa induces $\mathrm{b}^{0,+}$ and $\mathrm{y}^{+}$amino acid transport activities in Xenopus laevis oocytes. Journal of Biological Chemistry 267, 15384-15388.

Mailliard ME, Stevens BR \& Mann GE (1995) Amino acid transport by small intestinal, hepatic and pancreatic epithelia. Gastroenterology 108, 888-910.

Matthews JC, Wong EA, Bender PK \& Webb KE (1996) Demonstration and characterization of a transport system capable of lysine and leucine absorption that is encoded for in porcine jejunal epithelium by expression of mRNA in Xenopus laevis oocytes. Journal of Animal Sciences 74, 127-137.

Mendizábal MV, Idoate I, Jordán J \& Larralde J (1991) Effects of cefroxadine on L-leucine absorption in rat jejunum. Archives International of Physiology, Biochemistry and Biophysics 99, 247-250.

Mendizábal MV, Idoate I \& Larralde J (1990) Effect of cefatrizine and cephaloglycine on L-leucine absorption in rat jejunum. Comparative Biochemistry and Physiology 96C, 317-320.

Monteiro JB, Jordán J, Barber A \& Larralde J (1993) Effect of fluoxetine on the digestion and absorption of carbohydrates. Journal of Clinical Nutrition and Gastroenterology 8, 13-20.
Munck BG (1989) Amino acid transport across the hen colon: interactions between leucine and lysine. American Journal of Physiology 256, G532-G537.

Munck LK (1995) Chloride-dependent amino acid transport in the small intestine: occurrence and significance. Biochimica et Biophysica Acta 1241, 195-213.

Naftalin RJ \& Curran PF (1976) Galactose transport in rabbit ileum. Journal of Membrane Biology 16, 257-278.

O'Kane M, Wiles PG \& Wales JK (1994) Fluoxetine in the treatment of obese patients. Diabetes Medica 11, 105-110.

Pickel VM, Niremberg MJ, Chan J, Moschkovitz R, Udenfriend S \& Tate SS (1993) Ultrastructural localization of a neutral and basic amino acid transporter in rat kidney and intestine. Proceedings of the National Academy of Sciences USA 90 , $7779-7783$.

Ponz F, Ilundain A \& Lluch M (1979) Methods for successive absorption with intestinal perfusion "in vivo". Revista Española de Fisiología 35 97-103.

Salvador MT, Rodríguez-Yoldi MC, Alcalde AI, Marco R \& Rodríguez-Yoldi MJ (1996) Serotonin-induced changes in L-leucine transport across rabbit jejunum. Life Sciences $\mathbf{5 9}$, $1269-1281$.

Shirazi-Beechey SP, Davies AG, Tebbutt K \& Beechey R (1990) Preparation and properties of brush-border membrane vesicles from human small intestine. Gastroenterology 98, 676-685.

Spring B, Wurtman J, Wurtman R, El-Khoury A, Goldberg H, McDeermott J \& Pingitore R (1995) Efficacies of dexfenfluramine and fluoxetine in preventing weight gain after smoking cessation. American Joumal of Clinical Nutrition 62, 11811187.

Steiner M, Steinberg S \& Stewart D (1995) Fluoxetine in the treatment of premenstrual syndrome. New England Journal of Medicine 332, 1529-1534.

Van Beers EH, Büller HA, Grand RJ, Einerhand AWC \& Dekker J (1995) Intestinal brush border glycohydrolases: structure function and development. Critical Reviews in Biochemistry and Molecular Biology 30, 197-262.

Wise S (1992) Clinical studies with fluoxetine in obesity. American Journal of Clinical Nutrition 55, 181S-184S.

Wong DT, Bymaster FP, Horng JS \& Meloy BB (1975) A new selective inhibitor for uptake into synaptosomes of rat brain: 3-(p-trifluoromethylphenoxy)-N-methyl-3-phenylpropilamine. Journal of Pharmacology and Experimental Therapeutics 193, 804-811.

Wong DT \& Yen TT (1985) Suppression of appetite and reduction of body weight in normal and obese mice by fluoxetine, a selective inhibitor of serotonin uptake. Federation Proceedings 44, 1162 . 